\title{
Fusarium 属の産生するマイコトキシンの同時分析法
}

\author{
上村尚*
}

H. KAMIMURA*: Simultaneous detection of several mycotoxins from

Fusarium species in cereals and foodstuffs

Fusarium 属の産生するマイコトキシンの穀類における自然污染例として，日本では deoxynivalenol および nivalenol による単独または複合污染例が，諸外国では zearalenone, T-2 toxin など の污染例が報告されている ${ }^{1 \sim 3)}$. 我が国は，穀類などの輸入農産物が非常に多いことなどから， Fusarium 毒素群の同時分析法あるいは系統分析法の確立が必要と思われる.

従来，マイコトキシンの食品中からの分析法は，一般に液一液抽出法が用いられていた。しかし， この方法は，污染率が高いと考えられる nivalenol に応用できない欠点を有している.

そこで，穀類，豆類，種実類など広範囲の食品中の Fusarium 毒素群を対象とした系統的試験法 について種々検討したところ，試料にメタノール・水を加え抽出後，アンバーライトXAD-4 カラ ムクロマトグラフィー，ついでフロリジルカラムクロマトグラフィーによるクリーンアップを行っ た後，定性は薄層クロマトグラフィー，定量はガスクロマトグラフィーおよび薄層デンシトメトリ 一により，良好な結果が得られた。

\section{実 験 方 法 \\ 1. マイコトキシン}

Fusarium 属の産生するマイコトキシンのうち標品の得られた trichothecene 系マイコトキシン (nivalenol, deoxynivalenol, fusarenon-X, diacetoxyscirpenol, neosolaniol, T-2 toxin, HT-2 toxin, T-2 triol, T-2 tetraol), zearalenone, butenolide および moniliformin の計12種類を対象とした.

\section{2. アンバーライト XAD-4 カラムの作製}

アンバーライトXAD-4 樹脂（オルガノ株社製）を共栓フラスコに取り，水洗後， $1 \mathrm{~N} \mathrm{NaOH}$ を 加え振とうし水層を除去した。さらに水を加え，水層が中性になるまで水洗をくり返した。次いで メタノール，さらに熱メタノールで洗浄後，水洗を行い，メタノールを除去したのち用いた。 内径 $1.5 \mathrm{~cm}$ のカラム管に高さが $10 \mathrm{~cm}$ になるまでアンバーライトXAD-4 樹脂を充てんしたカラムを 作製した.

\section{3. フロリジルカラムの作製}

フロリジル（岩井化学社製） $10 \mathrm{~g}$ を内径 $1.5 \mathrm{~cm}$ のカラム管にクロロホルム・メタノール（9： 1) 混液を用いて充てんし，さらに無水硫酸ナトリウム $5 \mathrm{~g}$ を積層させたカラムを作製した.

\section{4. 試験溶液の調製}

良く粉砕した試料 $100 \mathrm{~g}$ を秤取し，メタノール・水（9:1）混液 $200 \mathrm{ml}$ を加え，30分間振とう

* 東京都立衛生研究所 ( 160 東京都新宿区百人町3-24-1)

Tokyo Metropolitan Research Laboratory of Public Health (24-1 Hyakunin-cho 3-chome, Shinjuku-ku, Tokyo 160) 
後, 万過した. 万液を正確に $100 \mathrm{ml}$ 分取し，減圧下で約 $10 \mathrm{ml}$ になるまで濃縮した。濃縮液はア ンバーライトXAD-4 カラムに負荷した. カラムに水 $50 \mathrm{ml}$ を通し, moniliformin を溶出後, 水を できるだけ溶出した後メタノール $20 \mathrm{ml}$ を加え，生じた気泡をガラス棒でゆるやかに䁌拌除去した のち,メタノール $80 \mathrm{ml}$ を用いて trichothecene 系マイコトキシン, butenolide および zearalenone を溶出した。 得られたメタノールは減圧下で濃縮乾固した。残留物にクロロホルム・メタノール （9:1）混液 $10 \mathrm{ml}$ を加え, 溶解後, フロリジルカラムクロマトグラフィー用の試料溶液とした. これをあらかじめ調製したフロリジルカラムに負荷したのち，クロロホルム・メタノール $(9: 1)$ 混液 $100 \mathrm{ml}$ を用いて溶出し, 溶離液は減圧下で濃縮乾固後, 残留物にメタノール $1 \mathrm{ml}$ を加え, 溶 解したものを試験溶液 1 とした。

一方，アンバーライトXAD-4 カラムより溶出した水層はエタノールを加え, 減圧下で濃縮乾固 した. 残留物にメタノール $5 \mathrm{ml}$ を加え，溶解後、アセトン $15 \mathrm{ml}$ を加え，生じた沈でんを沪別し， ろ液を減压下で濃縮乾固した。残留物にメタノール $1 \mathrm{ml}$ を加え，溶解したすのを試験溶液 2 とし た.

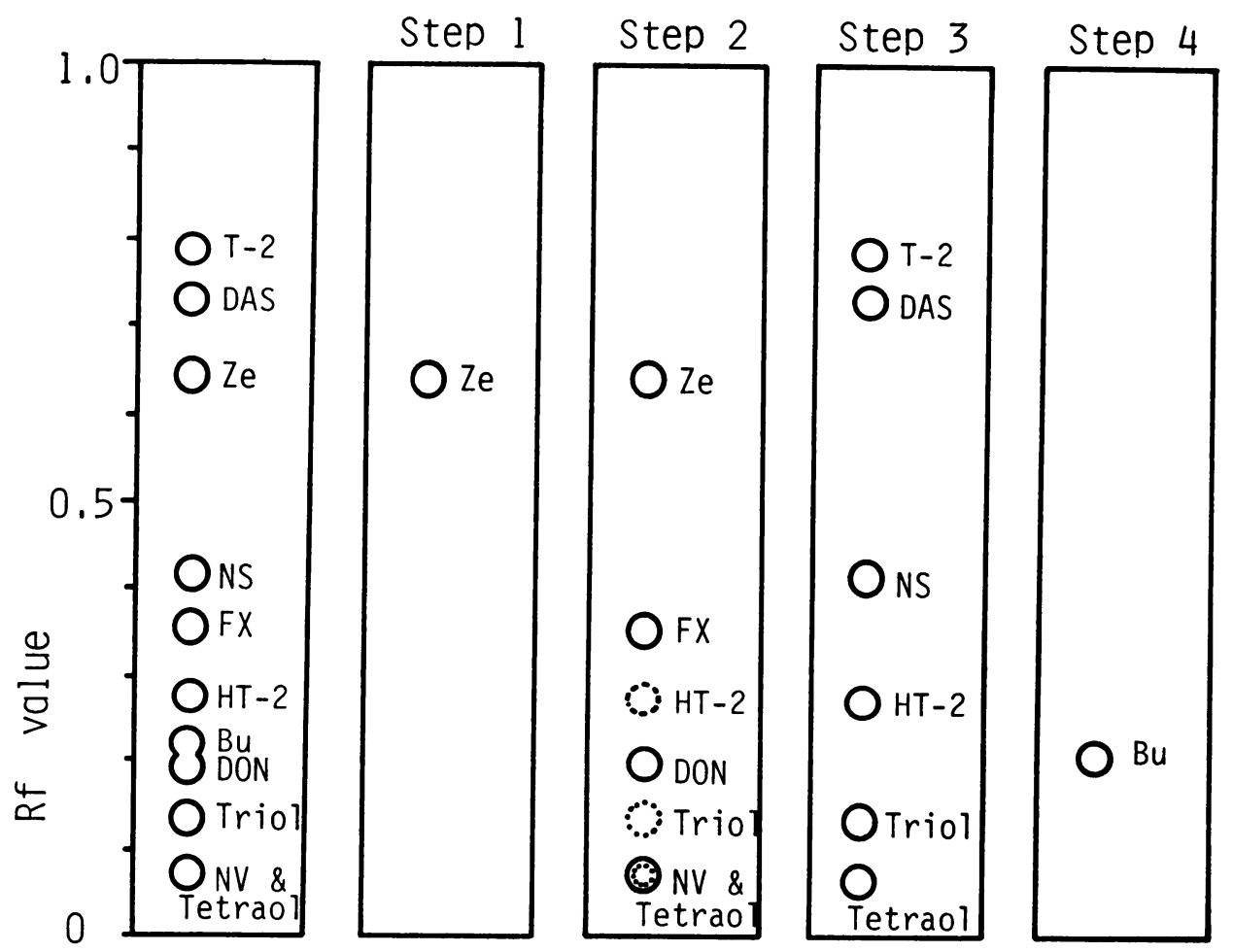

Fig. 1. Thin layer chromatograms of mycotoxins

NV, nivalenol; DON, deoxynivalenol; FX, fusarenon-x; DAS, diacetoxyscirpenol; NS, neosolaniol; T-2, T-2 toxin; HT-2, HT-2 toxin; Triol, T-2 triol; Tetraol, $\mathrm{T}-2$ tetraol; $\mathrm{Ze}$, zearalenone; $\mathrm{Bu}$, butenolide.

Developing solvent: $\mathrm{CHCl}_{3}$-methanol (93:7)

Treatment-step 1: observe under UV light step 2: spray with $20 \% \mathrm{AlCl}_{3}$ step 3: spray with $20 \% \mathrm{H}_{2} \mathrm{SO}_{4}$ step 4: spray with $0.3 \% 2$, 4 -dinitrophenylhydrazine 


\section{5. 薄層クロマトグラフィーによる定性}

試験溶液 1 および 2 について薄層クロマトグラフィーにより，トキシンの有無の確認を行った。

試験溶液 1 および11種類のマイコトキシン混合溶液を Kiesel gel 60 プレート (Merck 社製 Art. 5721) に塗布し，展開溶媒としてクロロホルム・メタノール $(93: 7)$ を用い薄層クロマトグラフ イーを行った. 展開後, 四段階の操作方法により各トキシンの検出を行った. それらのクロマトグ ラムを Fig. 1 に示した. 第一段階として $365 \mathrm{~nm}$ および $254 \mathrm{~nm}$ の紫外線照射によりいずれの波長 でもけい光を有する zearalenone のスポットを確認した．第二段階として20\%塩化アルミニウム・ エタノール溶液を噴霧し， $110^{\circ}, 10$ 分間加熱後, $365 \mathrm{~nm}$ の紫外線照射により nivalenol, deoxynivalenol, fusarenon-X および増けい光された zearalenone の他に，けい光強度は弱くなるが HT-2 toxin, T-2 triol および T-2 tetraol の確認も併せて行った. 第三段階として20\%硫酸を同一プレー トに噴霧し， $110^{\circ}, 10$ 分間加熱後， $365 \mathrm{~nm}$ の紫外線照射により， diacetoxyscirpenol, neosolaniol, T-2 toxin, HT-2 toxin, T-2 triol および T-2 tetraol のけい光スポットの確認を行った. Rf 值が 同一である nivalenol および T-2 tetraol はこれらの操作により判別するてとが可能であった. 塩 化アルミニウムを噴蓩すると nivalenol は強く，T-2 tetraol は弱いけい光を有した. しかし，同 一プレート上に硫酸を噴霧すると nivalenol のけい光は消失し， T-2 tetraol は增けい光するとと により，いずれかを判定できた。さらに 0.3\% 2,4-dinitrophenylhydrazine (DNPH) 塩酸溶液を 噴霧し, $110^{\circ}, 10$ 分間加熱後, butenolide の黄色スポットの確認を行った。

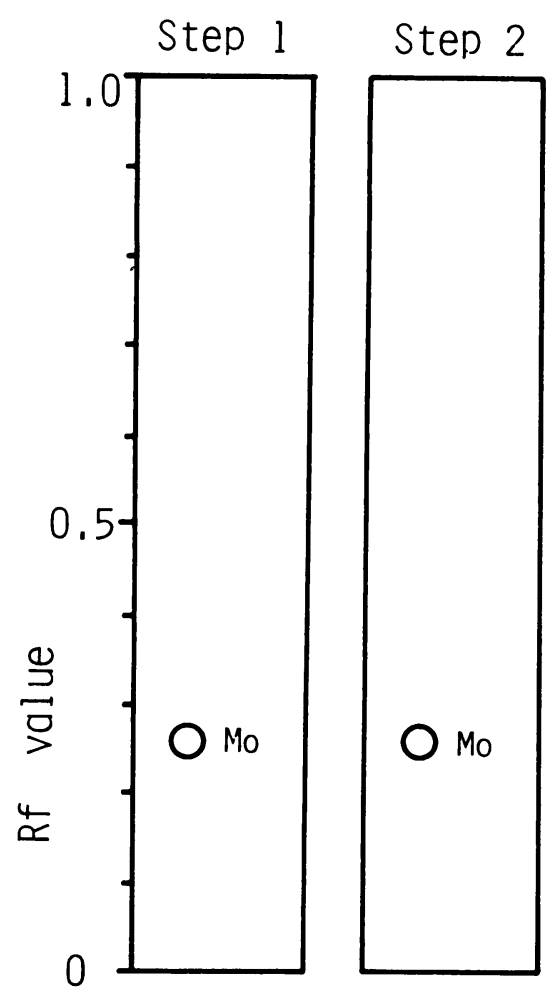

Fig. 2. Thin layer chromatograms of moniliformin

Mo, moniliformin

Developing solvent: toluene-acetone-methanol $(5: 3: 2)$

Treatment-step 1: observe under UV light,

step 2: spray with $0.3 \%$ 2,4-dinitrophenylhydrazine 
一方，試験溶液 2 および moniliformin 標準溶液を Kiesel gel $60 \mathrm{~F}_{254}$ プレート(Merck 社製 Art. 5715) に鈝布し，展開溶媒として，トルェン・アセトン・メタノール（5:3:2）を用いた薄 層クロマトグラフィーを行った. 展開後のプレートに $254 \mathrm{~nm}$ の紫外線照射により moniliformin の吸収スポットを確認後，0.3\%2,4-DNPH 塩酸溶液を噴霧し， $110^{\circ}, 10$ 分間加熱後, 褐色のスポ ットを確認した. 発色後のクロマトグラムを Fig. 2 に示した.

これらの薄層クロマトグラフィーによりトキシンの有無を確認後, ガスクロマトグラフィーおよ び薄層デンシトメトリーにより各トキシンの定量を行った.

\section{6. ガスクロマトグラフィー}

\section{6-1 FID ガスクロマトグラフィー}

試験溶液 1 を $0.5 \mathrm{ml}$ 秤取し, 減圧下で濃縮乾固後, 残留物にシリル化剂 (TSIM・TMCS・酢酸 エチル $1: 0.2: 9)$ を $0.5 \mathrm{ml}$ 加え密封し，15分間室温に放置後，ガスクロマトグラフに付した. 条件は充てん剂として $2 \%$ OV-17 を用い，カラム温度 $240^{\circ}$ チッ素流量 $50 \mathrm{ml} / \mathrm{min}$ で測定した. シリル化後の trichothecene 系マイコトキシンおよび zearalenone のガスクロマトグラムを Fig. 3

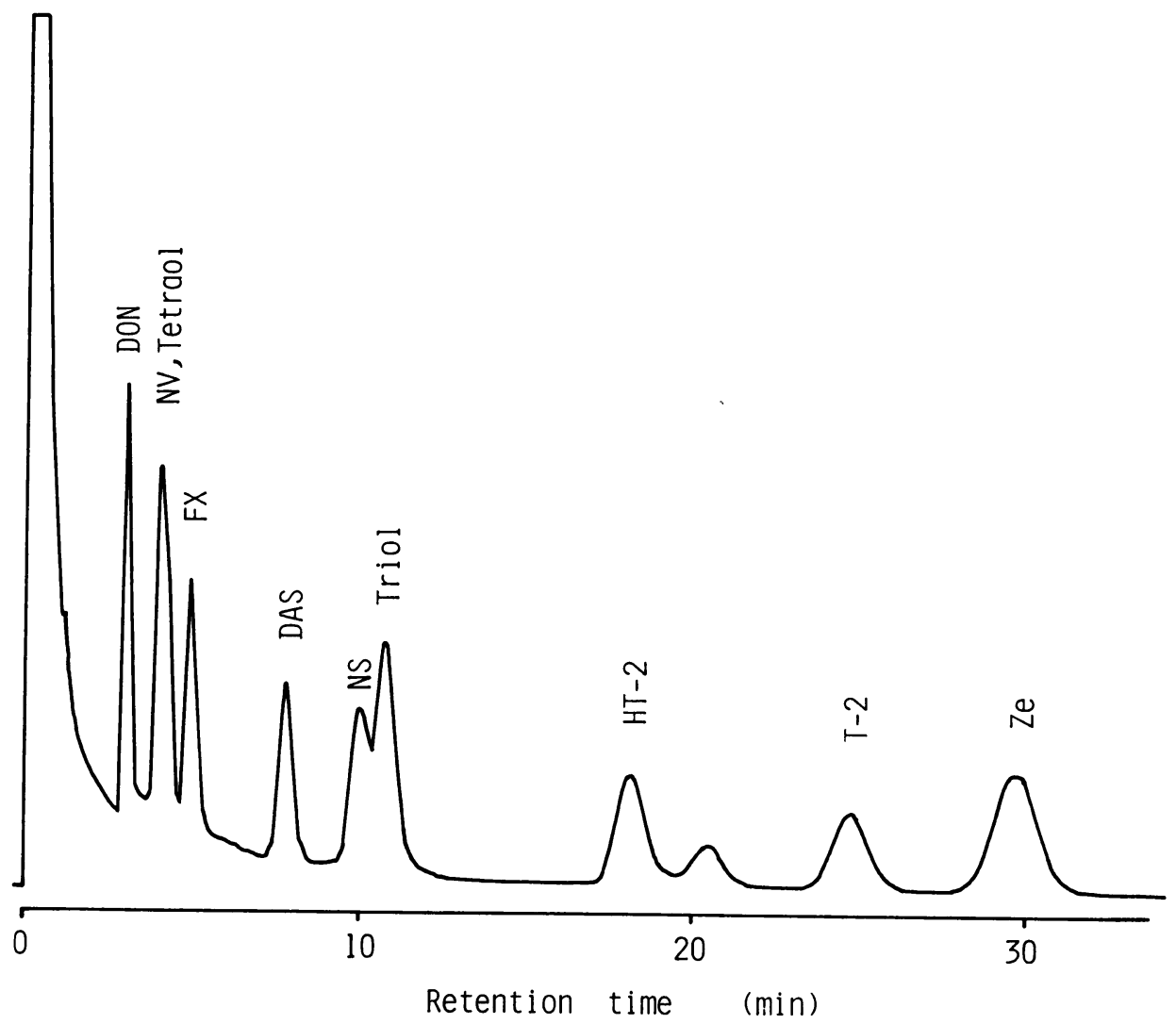

Fig. 3. Gas chromatogram of TMS-derivatives of mycotoxins DON, deoxnivalenol; NV, nivalenol; FX, fusarenon-x; DAS, diacetoxyscirpenol; NS, neosolaniol; T-2, T-2 toxin; HT-2, HT-2 toxin; triol, T-2 triol; Tetraol, $\mathrm{T}$-2 tetraol; $\mathrm{Ze}$, zearalenone.

Column condition: $2 \%$ OV-17 on $80-100$ mesh Gas Chrom Q. carrier gas flow rate, $50 \mathrm{ml} / \mathrm{min}$. column temperature, $240^{\circ}$. 


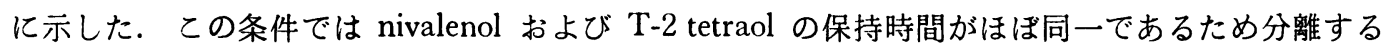
ことは困難であった，そてで nivalenol および T-2 tetraol の分離を目的として，カラム温度 $210^{\circ}$ で測定したときのクロマトグラムを Fig. 4 に示した.

\section{6-2 ECD ガスクロマトグラフィー}

deoxynivalenol, nivalenol および fusarenon-X などは保持時間が短いため，食品によっては妨害 を受けることが考えられる. そてで ECD ガスクロマトグラフィーの検討を行った．FID ガスク ロマトグラフィー用試験溶液に酢酸エチル $20 \mathrm{ml}$ を加え, 希釈後 ${ }^{63} \mathrm{Ni}$ を用いた $\mathrm{ECD}$ ガスクロマ トグラフィーを行った．条件は，充てん剂として FID 同様 $2 \%$ OV-17 を用い，カラム温度 $240^{\circ}$, 検出器温度 $280^{\circ}$, チッ素流量 $40 \mathrm{ml} / \mathrm{min}$ で測定した.

\section{7. 薄層デンシトメトリー}

butenolide および moniliformin の定量を目的として薄層デンシトメトリ一を行った.

試験溶液 1 は $0.2 \mathrm{ml}$, 試験溶液 2 は $0.5 \mathrm{ml}$ をそれぞれ減圧下で濃縮乾固後, あらかじめへキサ ンで洗浄した $0.3 \% 2,4-\mathrm{DNPH}$ 塩酸溶液を $1 \mathrm{ml}$ 加え, 䚌拌後, $50^{\circ}$ の水浴中で 90 分間加熱した. 加熱後, 分液ロートに水および少量のアセトンを用いて移した。試験溶液 1 (butenolide) は酢酸

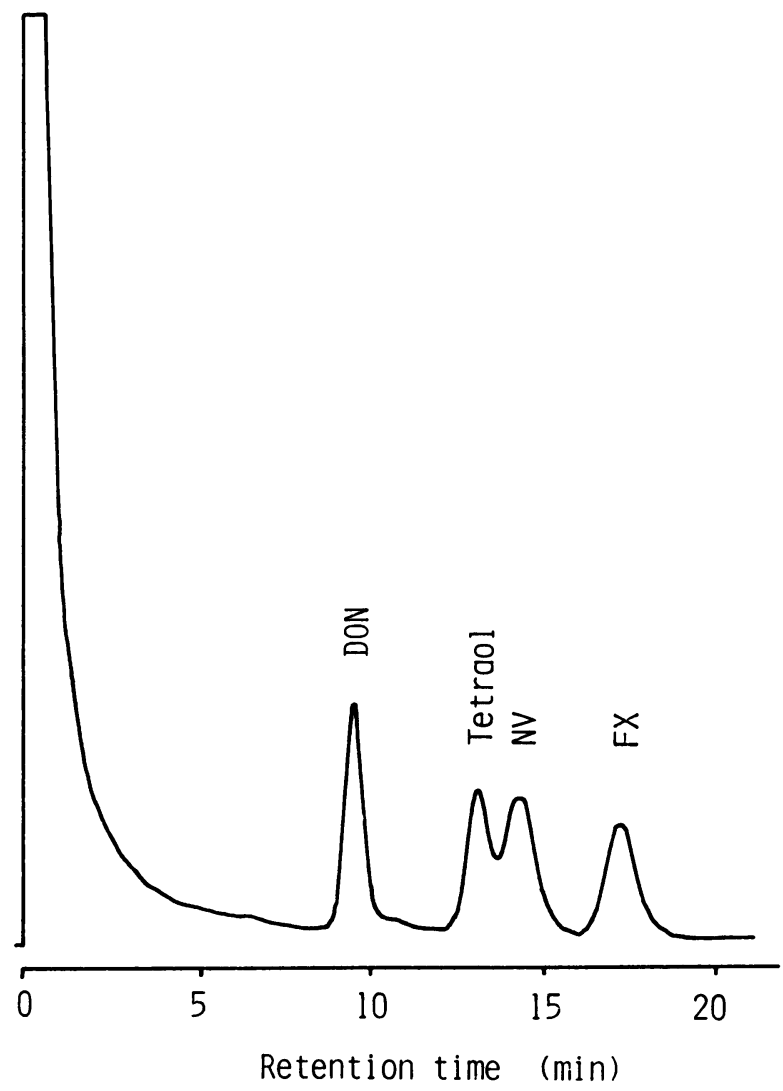

Fig. 4. Gas chromatogram of TMS-derivatives of mycotoxins DON, deoxynivalenol; NV, nivalenol; FX, fusarenon-x; Tetraol, T-2 teraol. Column condition: $2 \%$ OV-17 on $80-100$ mesh Gas Chrom Q. carrier gas flow rate, $50 \mathrm{ml} / \mathrm{min}$. column teperature, $210^{\circ}$. 
エチルで抽出し，試験溶液 2 (moniliformin) はクロロホルムで抽出を行い，無水硫酸ナトリウム で脱水後，減圧下で濃縮乾固した．残留物をアセトン $1 \mathrm{ml}$ で溶解したものを薄層デンシトメトリ 一用試験溶液とした。乙の試験溶液をそれぞれ Kiesel gel 60 プレートに塗布し，さらに同一プレ 一ト上に 2,4-DNPH 誘導体とした標準品を梁布後, 展開溶媒として butenolide-DNPH 用とし てトルェン・アセトン・メタノール (5:1:1), moniliformin-DNPH 用としてトルェン・ア セトン (97：3) を用いて展開した。展開後のプレートをよく風乾し，波長 $430 \mathrm{~nm}$ (butenolideDNPH) および $460 \mathrm{~nm}$ (moniliformin-DNPH) の条件で薄層デンシトメトリーを行った.

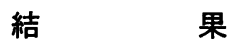

\section{1. 検出限界}

本法による検出限界は Table 1 に示したとおりであり，測定方法により検出限界は異なるが， ECD ガスクロマトグラフィーにより nivalenol タイプのトキシンは $0.002 \mathrm{ppm}$ また薄層デンシ トメトリーにより, butenolide は $0.03 \mathrm{ppm}$, moniliformin は $0.05 \mathrm{ppm}$ の高感度が得られたてと から, trichothecene 系マイコトキシンおよび zearalenone は FID ガスクロマトグラフィーで測定 し， nivalenol タイプのトキシンが検出または疑いがあたれた場合は ECD ガスクロマトグラフィ 一を用い, butenolide および moniliformin は薄層デンシトメトリーで測定した.

Table 1. Minimum detectable concentration $(\mu \mathrm{g} / \mathrm{kg})$ of mycotoxins

\begin{tabular}{lcccc}
\hline & \multicolumn{3}{c}{ Detection limits $(\mu \mathrm{g} / \mathrm{kg})$} \\
\cline { 2 - 5 } Mycotoxins & Qualitative & \multicolumn{3}{c}{ Quantitative } \\
\cline { 2 - 5 } & TLC & GC-FID & GC-ECD & TLC \\
\hline Nivalenol & $20-50$ & 100 & 2 & $20-50$ \\
Deoxynivalenol & $20-50$ & 100 & 2 & $20-50$ \\
Fusarenon-X & $20-50$ & 100 & 2 & $20-50$ \\
Diacetoxyscirpenol & $100-500$ & 200 & 80 & $100-500$ \\
Neosolaniol & $100-500$ & 200 & 80 & $100-500$ \\
T-2 toxin & $100-500$ & 200 & 80 & $100-500$ \\
HT-2 toxin & $100-500$ & 200 & 80 & $100-500$ \\
T-2 triol & $100-500$ & 200 & 80 & $100-500$ \\
T-2 tetraol & $100-500$ & 100 & 80 & $100-500$ \\
Zearalenone & $10-50$ & 100 & - & $10-50$ \\
Butenolide & $100-500$ & - & - & $30-50$ \\
Moniliformin & $200-500$ & - & - & $50-100$ \\
\hline
\end{tabular}

Table 2. Concentrations of mycotoxins in naturally infected barley and wheat harvested in Japan

\begin{tabular}{ccccc}
\hline Sample & $\begin{array}{c}\text { No. of } \\
\text { samples }\end{array}$ & $\begin{array}{c}\text { No. of } \\
\text { positives }\end{array}$ & Nivalenol & Deoxynivalenol \\
\cline { 4 - 5 } Wheat & 18 & 15 & $\begin{array}{c}\operatorname{tr}-7.8 \\
(1.5)\end{array}$ & $\begin{array}{c}\operatorname{tr}-4.7 \\
(1.0)\end{array}$ \\
Barley & 25 & 19 & $\begin{array}{l}\operatorname{tr}-36.9 \\
(3.9)\end{array}$ & $\begin{array}{c}\operatorname{tr}-40.4 \\
(4.4)\end{array}$ \\
\hline
\end{tabular}

Values in parentheses indicate the average 


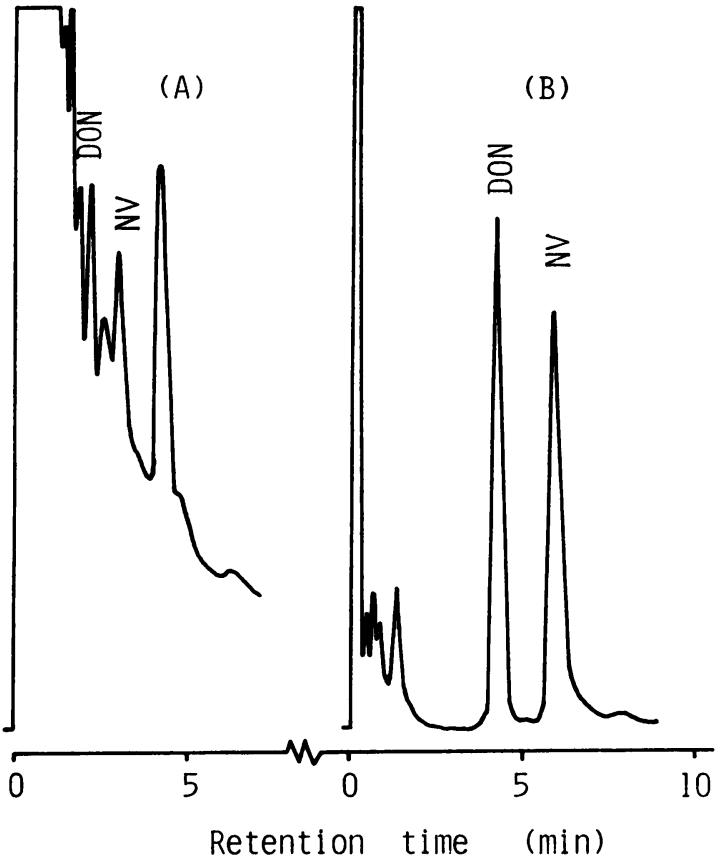

Fig. 5. Gas chromatograms of the silylated extracts from naturally infected barley contaminated with $1.8 \mu \mathrm{g} / \mathrm{g}$ deoxynivalenol (DON) and $1.4 \mu \mathrm{g} / \mathrm{g}$ nivalenol (NV)

(A)-Gas chromatogram of flame ionization detection. GC condition: carrier gas flow rate, $50 \mathrm{ml} / \mathrm{min}$. column temperature, $240^{\circ}$.

(B)-Gas chromatogram of electron capture detection. GC condition: carrier gas flow rate, $40 \mathrm{ml} / \mathrm{min}$. column temperature, $240^{\circ}$.

\section{2. 添加回収実験}

今回対象とした 12 種類のトキシンをコーン，大麦，精白米などの穀類に 1 2 $\mathrm{ppm}$ となる様に添 加し，回収実験を行ったところ，いずれむ71\%以上の回収率が得られた。

\section{3. 污染調查}

本法を用いて，1977年度国内産污染麦（香川大 芳沢博士より分与）について試験した結 果を Table 2 および Fig. 5 に示した. また市販の穀類およびそれらの製品などについて調 査を行って いるが現在のとてろトキシンは検出されていない.

本法は Fusarium 毒素の同時分析法として，収穫段階の穀類および市販品のモニタリングへの 応用に有効であると考える.

\section{参 考 文 献}

1) Mirocha, C. J., Schauerhamer, B., Pathre, S. V.: J. Assoc. Off. Anal. Chem., 57, 1104 (1974).

2) Yoshizawa, T., Tsuchiya, Y., Teraura, M., Morooka, N.: Proc. Jap. Assoc. Mycotoxicol., 2, 30 (1976).

3) Mirocha, C. J., Schauerhamer, B., Christensen, C. M., Kommedahl, T.: Appl. Environ. Microbiol., 38, 557 (1979). 